\title{
Chemical Composition of the Essential Oil of Phlomis linearis Boiss. \& Bal., and Biological Effects on the CAM-Assay: A Safety Evaluation
}

Betül Demirci ${ }^{\mathrm{a}, \mathrm{b}, *}$, Mehmet Y. Dadandic ${ }^{\mathrm{c}}$, Dietrich H. Paper ${ }^{\mathrm{b}}$, Gerhard Franz ${ }^{\mathrm{b}}$, and Kemal Hüsnü Can Başer ${ }^{\mathrm{a}}$

a Department of Pharmacognosy, Faculty of Pharmacy, Anadolu University, 26470 Eskişehir, Turkey. E-mail: bdemirca@anadolu.edu.tr

b Department of Pharmaceutical Biology, Faculty of Chemistry and Pharmacy, University of Regensburg, 93040 Regensburg, Germany

c Department of Biology, Faculty of Science and Letters, Erciyes University, 38039 Kayseri, Turkey

* Author for correspondence and reprint requests

Z. Naturforsch. 58c, 826-829 (2003); received June 20/August 15, 2003

Phlomis linearis Boiss. \& Bal. of the Lamiaceae family growing in central, east and southeast Anatolia is an endemic species for Turkey. The essential oil obtained from the aerial parts by hydro distillation was subsequently analyzed by GC/MS. The main components of the oil were found as $\beta$-caryophyllene $(24.2 \%)$, germacrene D $(22.3 \%)$ and caryophyllene oxide $(9.2 \%)$, among 49 identified compounds, representing $94.5 \%$ of the total essential oil. The overall biological activity of the essential oil (100 $\mu \mathrm{g} / \mathrm{pellet})$ was tested on the chorioallantoic membrane (CAM) of the fertilized hen's egg in order to examine the anti-angiogenic and anti-inflammatory activity. None of the tests showed pronounced activity, toxicity or irritation at the tested concentration.

Key words: Phlomis linearis, Essential Oil, CAM-Assay

\section{Introduction}

The genus Phlomis as perennial herbs or shrubs of Lamiaceae are represented by thirty four species of which twenty one are endemic for Turkey (Huber-Morath, 1982). The leaves and flowers of Phlomis species are used as aromatic amara, carminative, stimulant and are locally known as "Ballıkotu, Calba, Çalba, Şalba" in Turkish traditional medicine (Baytop, 1997, 1999). The endemic species Phlomis linearis Boiss. \& Bal. grows in steps, rocky igneous slopes, volcanic rubble at 1400 to $2400 \mathrm{~m}$ and has a distribution area from central to east and southeast Anatolia. This species is distinguished by a wide tubular calyx with a leave size 4 to 8 times longer than the width. The calyx and bracteoles also contain intense long hairs, the corolla is two lipped, generally in yellow and the upper lip is occasionally brownish (Dadand1, 2002)

Chemical constituents of Phlomis linearis have been investigated by Çalış and co-workers (1990, 1991); new glycosides, iridoids, neolignans, and their derivatives have been isolated. Some Phlomis species have also been investigated for both their biological activities and essential oil compositions by different groups (Mirza and Nik, 2003; Couladis et al., 2000; Sokovic et al., 2002a,b; Ristic et al., 2000)

The in vivo application on the chorioallantoic membrane of the fertilized egg (CAM-assay) is a useful and well established method to determine anti-angiogenic and anti-inflammatory activity of individual compounds or complex plant extracts. It can be used for testing natural compounds in small amounts for revealing various modes of action and the complex mechanisms related to angiogenesis and inflammation. Furthermore, possible side effects such as membrane irritation, toxic and anticoagulant properties of the investigated material in question can be revealed (Paper, 1998; D'Arcy and Howard, 1967; Bürgermeister et al., 2002; and references cited herein).

In this study, we have isolated the volatiles by water distillation from the aerial parts of $P$. linearis. The essential oil was then analyzed by gas chromatography/mass spectroscopy (GC/MS). To evaluate the essential oil and its potential anti-angiogenic and anti-inflammatory activity, the CAMassay was employed. 


\section{Methods and Materials}

\section{Plant material}

Aerial parts of the plant were collected from a step area in Kayseri, Erciyes Mountain, at about $2000 \mathrm{~m}$, on July 24, 2002, by one of us (M.Y.D.) and M. G. Halıc1. A voucher specimen (MYD1621) was kept at the Herbarium of Erciyes University, Faculty of Science and Letters.

\section{Isolation of the essential oil}

The aerial parts were dried in shade at room temperature. The essential oil was obtained by water distillation using a Clevenger type apparatus for $3 \mathrm{~h}$ having a yield of $0.05 \%(\mathrm{w} / \mathrm{v})$.

\section{Gas chromatography mass spectrometry}

The essential oil was analysed by gas chromatography/mass spectrometry using a HewlettPackard GCD system. Innowax FSC column ( $60 \mathrm{~m} \times 0.25 \mathrm{~mm}, 0.25 \mu \mathrm{m}$ film thickness) was used with helium as carrier gas. GC oven temperature was kept at $60^{\circ} \mathrm{C}$ for $10 \mathrm{~min}$ and programmed to $220{ }^{\circ} \mathrm{C}$ at a rate of $4{ }^{\circ} \mathrm{C} / \mathrm{min}$, and then kept constant at $220^{\circ} \mathrm{C}$ for $10 \mathrm{~min}$ and programmed to $240{ }^{\circ} \mathrm{C}$ at a rate of $1^{\circ} \mathrm{C} / \mathrm{min}$. Split flow was adjusted at $50 \mathrm{ml} / \mathrm{min}$. The injector temperature was $250{ }^{\circ} \mathrm{C}$. Mass spectra were recorded at $70 \mathrm{eV}$. Mass range was from $m / z, 35$ to 425 . $n$-Alkanes were used as reference points in the calculation of relative retention indices (RRI). Relative percentages of the characterized components were as listed in Table I. Library search was carried out using both "Wiley GC/MS Library" and "Baser Library of Essential Oil Constituents".

\section{CAM-assay}

Sample preparation: The essential oil $(10 \mathrm{mg} / \mathrm{ml})$ was dissolved in a $2.5 \%(\mathrm{w} / \mathrm{v})$ agarose (Merck, Darmstadt) solution. For ease of application pellets of these solutions $(10 \mu \mathrm{l})$ were prepared and applied drop wise on circular teflon supports of $3 \mathrm{~mm}$ diameter, cooled to room temperature for solidification and applied on to the chorioallantoic membrane (CAM).

Preparation of the test medium: The fertilized hen's eggs were previously incubated for $65-72 \mathrm{~h}$ at $37{ }^{\circ} \mathrm{C}$ and a relative humidity of $80 \%$. The eggs were positioned in a horizontal position and ro-
Table I. The composition of the essential oil of Phlomis linearis.

\begin{tabular}{|c|c|c|}
\hline RRI & Compound & $\%$ \\
\hline 1479 & $\delta$-Elemene & $\operatorname{tr}$ \\
\hline 1497 & $\alpha$-Copaene & 0.3 \\
\hline 1528 & $\alpha$-Bourbonene & $\operatorname{tr}$ \\
\hline 1535 & $\beta$-Bourbonene & 1.4 \\
\hline 1553 & Linalool & 0.6 \\
\hline 1589 & $\beta$-Ylangene & 0.5 \\
\hline 1600 & $\beta$-Elemene & 0.7 \\
\hline 1612 & $\beta$-Caryophyllene & 24.2 \\
\hline 1650 & $\gamma$-Elemene & 0.1 \\
\hline 1668 & $(Z)$ - $\beta$-Farnesene & 6.6 \\
\hline 1687 & $\alpha$-Humulene & 3.5 \\
\hline 1704 & $\gamma$-Muurolene & 0.4 \\
\hline 1706 & $\alpha$-Terpineol & 0.2 \\
\hline 1726 & Germacrene D & 22.3 \\
\hline 1740 & $\alpha$-Muurolene & 1.4 \\
\hline 1755 & Bicyclogermacrene & 1.1 \\
\hline 1773 & $\delta$-Cadinene & 1.0 \\
\hline 1776 & $\gamma$-Cadinene & $\operatorname{tr}$ \\
\hline 1808 & Nerol & $\operatorname{tr}$ \\
\hline 1827 & $(E, E)-2,4-$ Decadienal & 0.2 \\
\hline 1838 & (E)- $\beta$-Damascenone & 0.3 \\
\hline 1857 & Geraniol & 0.5 \\
\hline 1868 & (E)-Geranyl acetone & 0.5 \\
\hline 1900 & Nonadecane & 0.2 \\
\hline 1958 & $(E)-\beta$-Ionone & 0.6 \\
\hline 2001 & Isocaryophyllene oxide & 0.8 \\
\hline 2008 & Caryophyllene oxide & 9.2 \\
\hline 2045 & Humulene epoxide-I & $\operatorname{tr}$ \\
\hline 2046 & Norbourbonone & 0.1 \\
\hline 2071 & Humulene epoxide-II & 0.7 \\
\hline 2095 & Hexyl benzoate & 0.2 \\
\hline 2131 & Hexahydrofarnesyl acetone & 5.8 \\
\hline 2179 & 3,4-Dimethyl-5-pentylidene-2(5H)-furanone & 0.6 \\
\hline 2198 & Thymol & 0.5 \\
\hline 2209 & T-Muurolol & 0.3 \\
\hline 2239 & Carvacrol & 1.2 \\
\hline 2255 & $\alpha$-Cadinol & 1.1 \\
\hline 2300 & Tricosane & 0.6 \\
\hline 2324 & $\begin{array}{l}\text { Caryophylla-2(12),6(13)-dien-5 } \alpha \text {-ol } \\
\text { (Caryophylladienol II) }\end{array}$ & 0.4 \\
\hline 2384 & Hexadecanol & 0.9 \\
\hline 2389 & $\begin{array}{l}\text { Caryophylla-2(12),6-dien-5 } \alpha \text {-ol } \\
\text { (Caryophyllenol I) }\end{array}$ & 0.1 \\
\hline 2392 & $\begin{array}{l}\text { Caryophylla-2(12),6-dien-5 } \beta \text {-ol } \\
\text { (Caryophyllenol II) }\end{array}$ & 1.1 \\
\hline 2400 & Tetracosane & 0.1 \\
\hline 2500 & Pentacosane & 1.3 \\
\hline 2600 & Hexacosane & $\operatorname{tr}$ \\
\hline 2622 & Phytol & 0.1 \\
\hline 2655 & Benzyl benzoate & 0.2 \\
\hline 2700 & Heptacosane & 1.7 \\
\hline 2900 & Nonacosane & 0.8 \\
\hline
\end{tabular}

RRI: Relative retention indices calculated against $n$-alkanes.

\%: calculated from TIC

tr: $\quad$ Trace $(<0.1 \%)$. 
tated several times. Then the eggs were opened on the snub side. Before the opening $10-15 \mathrm{ml}$ of albumin were aspirated from a hole on the pointed side. At two third of the height (from the pointed side) the eggs were traced with a scalpel and after that the shells were removed with forceps. The cavity was covered with film and the eggs were incubated at $37^{\circ} \mathrm{C}$ at a relative humidity of $80 \%$ for further $75 \mathrm{~h}$. If the formed CAM had approximately a diameter of $2 \mathrm{~cm}$ one pellet (1 pellet/egg) was placed on it. The eggs were incubated for one further day and then evaluated under the stereomicroscope. For every test compound 10-15 eggs were utilized.

Evaluation and scoring: For the evaluation of the effects, a scoring system was used (see Tables II and III). In brief; score: 0.5 , no anti-angiogenic effect; score: $0.5-1$, weak to medium anti-angiogenic effect; score: 1 , medium to strong anti-angiogenic effect. As controls suramin (Merck, Darmstadt) and sodium dodecyl sulphate (SDS) (Merck, Darmstadt) at the concentration of $50 \mu \mathrm{g} /$ pellet were also tested. As blank, CAMs treated with solidified agarose-solution in pellet form $(2.5 \%, \mathrm{w} / \mathrm{v})$ were also included. Each experiment was performed in triplicate (D'Arcy and Howard, 1967; Bürgermeister et al., 2002).

\section{Results and Discussion}

The chemical compositions of various Phlomis species have been investigated. However, to the best of our knowledge this is the first investigation of the volatile fraction of $P$. linearis. The hydrodistillation of the aerial parts yielded a yellowish essential oil with a pleasant odour, however in a poor yield. Subsequent GC/MS analysis resulted in detection and identification of 49 components representing $94.5 \%$ of the total oil composition (Table I). Sesquiterpene hydrocarbons were the major volatiles with $\beta$-caryophyllene ( $24.2 \%)$, germacrene $\mathrm{D}(22.3 \%)$, and $(Z)-\beta$-farnesene $(6.6 \%)$, respectively. Oxygenated sesquiterpenes were present mostly as epoxides like caryophyllene oxide $(9.2 \%)$. Noteworthy was the presence of various caryophyllene derivatives in different amounts that probably contribute to the characteristic odour of the oil. Oxygenated monoterpenes and monoterpene hydrocarbons were the minor portion of the whole oil which certainly also have impacts to the odour.

Due to the ethno-botanical use and various biological activities of Phlomis species we have also subjected the essential oil for potential anti-angiogenic and anti-inflammatory activity evaluation using the CAM-assay. At $100 \mu \mathrm{g} /$ pellet the essential oil showed a very weak angiogenic effect compared to standard substances (Table II and III). When applied to the CAM the essential oil showed at this concentration neither toxic, nor irritant effects.

The essential oil composition of Phlomis olivieri Benth. from Iran was very recently reported, sesquiterpenes were among the major components with germacrene $\mathrm{D}(28.1 \%)$ and $\beta$-caryophyllene $(16.1 \%)$ of fifteen identified compounds (Mirza and Nik, 2003). Phlomis lanata Willd. essential oil was analyzed to reveal forty-eight compounds representing $97 \%$ of the oil where $\alpha$-pinene $(25.4 \%)$, limonene $(15.7 \%)$ and trans-caryophyllene $(8.8 \%)$ were found as major components (Couladis et al., 2000). Another study was on the essential oils from the leaves of Phlomis fruticosa L. Forty components were identified, $\beta$-caryophyllene (12\%), (E)-methyl isoeugenol $(15.3 \%)$ and $\alpha$-asarone

Table II. Effects of Phlomis linearis essential oil in the CAM-assay.

\begin{tabular}{|c|c|c|c|}
\hline Test Sample & Score* & Irritation (\%) & \\
\hline Phlomis linearis oil & $0.2 \pm 0.2$ & - & $100 \mu \mathrm{g} /$ pellet \\
\hline Agarose & $0.2 \pm 0.2$ & - & Blanc $(2.5 \%, \mathrm{w} / \mathrm{v})$ \\
\hline Sodium dodecyl sulphate (SDS) & 0 & $85 \pm 5$ & Negative control ( $50 \mu \mathrm{g} /$ pellet $)$ \\
\hline
\end{tabular}

* Formula for scoring:

Average score $=\frac{\text { Number of eggs }(\text { score } 2) \times 2+\text { number of eggs }(\text { score } 1) \times 1}{\text { Total number of eggs }(\text { score } 0,1,2)}$ 
Table III. Score values for the evaluation of the anti-angiogenic effect on the CAM.

\begin{tabular}{lll}
\hline Score & Effect & Observation/Interpretation \\
\hline 0 & no & Normal embryo formation. \\
0.5 & very weak & $\begin{array}{l}\text { No capillary free area. } \\
\text { Area with reduced density of capillaries around the pellet not larger than its own area. }\end{array}$ \\
1 & weak medium & $\begin{array}{l}\text { Small capillary free area or area with significantly reduced density of capillaries. } \\
\text { Effects not larger than double the size of the pellet. }\end{array}$ \\
2 & strong & Capillary free area around the pellet at least double the size of the pellet.
\end{tabular}

$(10.9 \%)$ as major compounds, respectively (Sokovic et al., 2002a). Phlomis fruticosa L. from two different localities in Yugoslavia were analyzed and investigated for their antimicrobial activities. Here, $\alpha$-pinene $(39-57 \%)$ was found to be the major constituent in both samples (Ristic et al., 2000).

Baytop T. (1997), Türkçe Bitki Adları Sözlüğü (Dictionary of Turkish Plant Names), TDK Yay., No. 280, Ankara, Turkey.

Baytop T. (1999), Türkiye'de Bitkiler ile Tedavi, Geçmişte ve Bugün (Therapy with Medicinal Plants in Turkey, Past and Present). Nobel Tip Basımevi, Istanbul, Turkey, $2^{\text {nd }}$ ed.

Bürgermeister J., Paper D. H., Vogl H., Linhardt R. J., and Franz G. (2002), LaPSvS1, a $(1 \rightarrow 3)-\beta$-galactan sulfate and its effect on angiogenesis in vivo and in vitro. Carbohydrate Res. 337, 1459-1466.

Couladis M., Tanimanidis A., Tzakou O., Chinou I. B., and Harvala C. (2000), Essential oil of Phlomis lanata growing in Greece: Chemical composition and antimicrobial activity. Planta Med. 66, 670-672.

Calış I., Başaran A. A., Saraçoğlu I., Sticher O., and Rüedi P. (1990), Phlinosides A, B and C, three phenylpropanoid glycosides from Phlomis linearis. Phytochemistry 29, 1253-1257.

Çalış I., Başaran A. A., Saraçoğlu I., Sticher O., and Rüiedi P. (1991), Phlinosides D and E, phenylpropanoid glycosides, and iridoids from Phlomis linearis. Phytochemistry 30, 3073-3076.

D'Arcy P. F. and Howard E. M. (1967), A new antiinflammatory test, utilizing the chorioallantoic membrane of the chick embryo. Br. J. Pharmac. Chemother. 29, 378-387.
Phlomis species are widely distributed in Turkey, however, composition of the essential oil has not been investigated thoroughly. This is also the case for their biological activities. Using the CAMassay other essential oils and major common components will be also tested in further work. Our studies on medicinal and aromatic Phlomis species are ongoing.

Dadandı M. Y. (2002), Türkiye'nin Phlomis L. (Lamiaceae) Cinsi Revizyonu [The Revision of the Phlomis L. (Lamiaceae) of Turkey]. Ph. D. Thesis, Institute of Science and Technology, Gazi University, Ankara, Turkey.

Huber-Morath A. (1982), Phlomis L. In: Flora of Turkey and East Aegean Islands Davis P. H., ed.). Edinburgh Univ. Press, Edinburgh, Vol. 7, pp. 102-126.

Mirza M. and Nik Z. B. (2003), Volatile constituents of Phlomis olivieri Benth. from Iran. Flavour Fragr. J. 18, 131-132.

Paper D. H. (1998), Natural Products as angiogenesis inhibitors. Planta Med. 64, 686-695.

Ristic M. D., Duletic-Lausevic S., Knezevic-Vukcevic J., Marin P. D., Simic D., Vukojevic J., Janackovic P., and Vajs V. (2000), Antimicrobial activity of essential oils and ethanol extract of Phlomis fruticosa L. (Lamiaceae). Phytother. Res. 14, 267-271.

Sokovic M. D., Marin P. D., Janackovic P., Vajs V., Milosavljevic S., Dokovic D., Tesevic V., and Petrovic S. (2002a), Composition of the essential oils of Phlomis fruticosa L. (Lamiaceae). J. Essent. Oil Res. 14, 167168

Sokovic M. D., Marin P. D., Simic D., Knezevic-Vukcevic J., Vajs V., and Petrovic S. (2002b), Antimutagenic activity of essential oil and crude extract of Phlomis fruticosa. Pharm. Biol. 40, 311-314. 